\title{
CHARACTERIZATION OF SELF-EXTERMINATION ATTEMPT CASES IN AN EMERGENCY DEPARTMENT IN A UNIVERSITY HOSPITAL
}

\author{
CARACTERIZAÇÃO DOS CASOS DE TENTATIVA DE AUTOEXTERMÍNIO EM UM \\ PRONTO SOCORRO DE UM HOSPITAL UNIVERSITÁRIO
}

\author{
Dieska Coelho QUINTILIANO ${ }^{1}$; Maria Cristina de Moura FERREIRA ${ }^{2}$ \\ 1. Enfermeira Residente Multiprofissional em Saúde, em Atenção ao Paciente em Estado Crítico, pela Universidade Federal de \\ Uberlândia -UFU, Graduada em Enfermagem pela Universidade Federal do Triângulo Mineiro - UFTM; 2.Professora, Doutora em \\ Enfermagem,. Faculdade de Medicina - FAMED - UFU.
}

\begin{abstract}
Violence becomes a matter to be discussed in the health-disease process, once it reaches the collective and individual health, requiring action and articulation of services. Suicide is the third leading cause of death in Brazil, however, these self-extermination attempts are not being successfully reported (under notified) and, sometimes, not even reported at all. This was a retrospective, cross-sectional study with a quantitative approach, to characterize the cases of self-extermination attempt in the emergency department of a university hospital. One-hundred and sixty two (162) medical records were included in self-extermination attempt cases, for the period of January 2008 to September 2013. Of the 162 analyzed records, $56.17 \%$ were women; $22.22 \%$ within the age group between 24 and 38 years old, average age of 34.5 years old; $53.09 \%$ single; $94.44 \%$ coming from Uberlândia; $39.51 \%$ occurred at night; frequency of $19.14 \%$ on Mondays; $24.68 \%$ of attempts in 2012. Abusive ingestion of medications in $34.07 \%$ of cases; $51.23 \%$ were brought to the hospital by the Fire Department; $35.83 \%$ had a mental disorder; $45.67 \%$ of the cases were the patient's first attempt; $39.42 \%$ of cases occurred after relationship conflicts ; $54.32 \%$ were discharged within 18 hours, on average, after care in the emergency room; $21.60 \%$ have returned because of a new attempt. The research was based on characterized attempts at self-extermination cases, with predominantly female, aged between 24 and 38, use of medication as an agent to act, with high recidivism among the female group. It is suggested research with longer periods and samples and analyzed by The National Policy for Reduction of Morbidity and Mortality by Accidents and Violence.
\end{abstract}

KEYWORDS: Suicide attempt. Violence. Emergency Medical Services.

\section{INTRODUCTION}

Violence is a phenomenon that is present throughout humankind's history, but becomes a health problem when affects individual and collective health, therefore requiring actions from the government and the development of new public policies such as prevention and circumstantial treatment (MINAYO, 2005).

According to the World Health Organization (WHO), violence was defined and accepted worldwide, from the World Report on Violence and Health in 2002 as "The intentional use of physical force or power, threatened or actual, against oneself, another person, or against a group or community, that either results in or has a high likelihood of resulting in injury, death, psychological harm, poor development or deprivation" (WHO, 2008, p. 5). From this definition, violence is divided into three categories: interpersonal violence, collective violence and self inflicted violence. This can be characterized by suicidal behavior, attempted suicide, completed suicide and self abuse (WHO, 2008).

In the overall context, all forms of violence have impacts on the societies they occur; however, the vast majority of violence actions are not collective. The determinants of interpersonal violence and self-directed violence stand higher than collective violence. There is an understanding by the nations that violence slows development. However, there is little emphasis on international development agendas on the subject, usually with a limited forward vision to interpersonal violence and almost no visibility to suicide (WHO, 2008).

Worldwide, according to WHO (2008), suicide reaches $54 \%$ of mortality from violence, and, of those who die from those causes, $60 \%$ are male. Thereby, the impact of suicide causes grave consequences not only at an economic level, but also to those who were familiar to the deceased, in both short and long-term basis (WHO, 2012).

In Brazil in 2010, according to data transferred by the Mortality Information System SIM, suicide corresponded to the third cause of death from external causes in the adult group aged between 20 and 59 years old, behind aggression and accidents by land transport; the percentage of selfextermination mortality between 20 to 39 years old was $6.4 \%$; between 40 and 59 deaths were $9.6 \%$; overall mortality in the country for suicide ranks is fifth in the group of external causes, with 9,448 
Characterization of self-extermination...

deaths reported in 2010. The risk of death between 2001 and 2010, increased between both sexes, with $10 \%$ increase in mortality risk for self-extermination in the age group 20-39 years old. In the Southeast, there was increase of $20 \%$ risk of death by selfinflicted violence (BRASIL, 2012). According to Sá and colleagues (2010), Brazil shows low suicide mortality rates, but in 2004 it was ranked ninth in absolute numbers for this cause of death.

National data are influenced by under notification, especially when attention turns to the information about a self-extermination attempt; adding the possibility of working with data not entirely reliable (MINAYO, 2005; SOUZA, MINAYO, CAVALCANTE, 2007; VIDAL, GONTIJO, LIMA, 2013). The cases of suicide attempts pervade by the fact that, once they reach the services, "the elaborated records in emergency departments or in emergency rooms usually tick only the secondary cause, the injury or trauma resulting from attempts that required medical care, which makes information unreliable" (MINAYO, 2005, p. 208).

The identification of such cases is among the first steps to develop a strategy (WHO, 2012). So making profiles helps build policies / actions that decrease the incidence and prevalence of attempts at self-extermination. For Minayo (2005), in quantitative production, it is necessary to produce knowledge about the magnitude of morbidity and mortality phenomena and factors that specify the perpetuation of the cases and express the priorities of action. Thus, it is possible to discuss programs that meet regional particularities and formulate effective actions for care and prevention.

Therefore, the aim of this study was to characterize the cases of self-extermination attempts in the emergency department of a university hospital.

\section{MATERIAL AND METHODS}

It is a descriptive, cross-sectional, and retrospective, with quantitative data approach. The survey was conducted at Clinical Hospital of the Federal University of Uberlândia (HCU - UFU).

The population consisted of 587 medical records, which contained information about the medical care carried out in the emergency room of the HCU - UFU to patients, with record of selfextermination attempts (ICD - 10 with X60 to X84 code that are related to intentional self-harm), from January 2008 to September 2013, held for sample size calculation, which consisted of 238 medical records. Simple random sampling was used, by
QUINTILIANO, D. C.; FERREIRA, M. C. M.

raffle of medical records, to compose the material to be analyzed.

In the data collection matter, an elaborate instrument was used for this purpose, being initiated after the project approval by the Research Ethics Committee - CEP / UFU, under the CAAE 26819914.4.0000.5152 number, similar to number 907,164 . This instrument had variables on the patient, such as age, gender, marital status and origin; aspects of the occurrence of an attempt to self-extermination such as the period, agent used, and means of transportation arrival; data on past history, motivation to act, evolution, previous and after suicide attempts, the first visit to the service.

The medical records with active status were included, with the registration of attempt to selfextermination, which belonged to the period mentioned. Where there was more than one entry for the same reason in the emergency room, the information of first entry was collected within the established period, later entrees were just quantified. The excluded records were those who owned less than $50 \%$ of the information necessary to fill in the collection instrument, those who had no clear indications of an attempt to self-extermination, consisting only of an act of threat, and medical records on inactive status or deceased.

Data were added into an electronic spreadsheet, Excel®. They were then transported to BioEstat 5.0 software for processing and analysis. The variables were analyzed using descriptive statistics.

\section{Statistical Analysis}

With interest in verifying the existence of differences whether or not statistically significant between the frequencies obtained by male or female patients, in dealing with agents used in attempts to self-extermination, the chi-square distribution (SIEGEL, 1975), was applied to the concerned data. For the results of this test to be significant, it is necessary that the values are greater than 3.84, according to the table of critics' values of chi-square (SIEGEL, 1975). The level of significance was set at 0.05 in a one-sided test.

\section{RESULTS}

238 medical records were analyzed, but 162 records were included with their respective selfextermination attempt report, according to the criteria of inclusion and exclusion proposed by the study. From these 162 patients, 71 (43.82\%) were men and $91(56.17 \%)$ were women. 
The average age of the subjects was 34.5 years old $(\mathrm{SD}=12.11)$, with a minimum age of 12 years and a maximum of 73 years. Table 1 shows the characterization of age of the study sample, according to gender.

Table 1. Presentation of minimum, maximum, average and standard deviation aged of patients who were admitted into the emergency room for attempted self-extermination, according to gender. Uberlândia, 2008-2013.

\begin{tabular}{lcccc}
\hline \multicolumn{1}{c}{ Variables } & Average & $\begin{array}{c}\text { Standard } \\
\text { Deviation }\end{array}$ & Minimum & Maximum \\
\hline Men & 34.8 & 13 & 14 & 73 \\
Women & 34.3 & 13 & 12 & 66 \\
Total & 34.5 & 12.11 & 12 & 73 \\
\hline
\end{tabular}

Whilst the prevailing age group was (46.30\%), as Table 2. between 24 and 38 years old, with 75 individuals

Table 2. Distribution by age group of patients who were admitted to the emergency room for attempted selfextermination. Uberlândia, 2008-2013.

\begin{tabular}{lccc}
\hline Average age & $\mathbf{n}$ & Average & \% \\
\hline 10 - 24 & 32 & 17 & 19.75 \\
$24-38$ & 75 & 31 & 46.30 \\
38 I-52 & 38 & 45 & 23.46 \\
52 - 66 & 14 & 59 & 8.64 \\
66 I- 80 & 3 & 73 & 1.85 \\
Total & 162 & - & 100.00 \\
\hline
\end{tabular}

It can be seen in table 3 higher frequency of single marital status of patients who were admitted to the emergency department for attempted selfextermination, with 86 cases $(53.09 \%)$.

Table 3. Distribution of absolute and relative frequencies of marital status of patients in the emergency department for attempted self-extermination, according to gender. Uberlândia, 2008-2013.

\begin{tabular}{lcccccc}
\hline Marital Status & \multicolumn{2}{c}{ Men } & \multicolumn{2}{c}{ Women } & \multicolumn{2}{c}{ Total } \\
\hline \multirow{3}{*}{ Single } & $\mathbf{N}$ & $\mathbf{\%}$ & $\mathbf{n}$ & $\mathbf{\%}$ & $\mathbf{\text { n }}$ \\
Married & 40 & 56.34 & 46 & 50.55 & 86 & 53.09 \\
Stable union & 22 & 30.99 & 22 & 24.18 & 44 & 27.16 \\
Separated & 03 & 4.23 & 16 & 17.58 & 19 & 11.73 \\
Widowed & 04 & 5.63 & 03 & 3.30 & 07 & 4.32 \\
Divorced & 01 & 1.41 & 03 & 3.30 & 04 & 2.47 \\
Total & 01 & 1.41 & 01 & 1.10 & 02 & 1.23 \\
\hline
\end{tabular}

Regarding the origin, there was a predominance of those who resided in the city of Uberlândia, 153 (94.44\%) among the patients. While, $08(4.94 \%)$ patients were from other cities, yet in the same region, the origin of $01(0.62 \%)$ patient was not recorded.
Referring to the time of day the attempt to self-extermination occurs, according to table 4 , a greater frequency distribution was observed at night, with 64 (39.51\%) reports of attempt to selfextermination. Regarding the day of the week, Mondays had the highest frequency of attempts, 
with $31(19.14 \%)$ cases recorded. As to the year of occurrence, within the period established by the survey, there was a higher frequency in the sample of 2012, with 40 cases $(24.68 \%)$.

Table 4. Distribution of absolute and relative frequencies about the recorded period of the day, the week and the year of occurrence of attempts to self-extermination. Uberlândia, 2008-2013.

\begin{tabular}{clcc}
\hline & & $\mathbf{n}$ & \% \\
\hline Time of day & Morning & 36 & 22.22 \\
& Afternoon & 62 & 38.27 \\
& Evening & 64 & 39.51 \\
& Total & 162 & 100.00 \\
\hline Days of the week & Monday & 31 & 19.14 \\
& Tuesday & 21 & 12.96 \\
& Wednesday & 23 & 14.20 \\
& Thursday & 15 & 9.26 \\
& Friday & 18 & 11.11 \\
& Saturday & 28 & 17.28 \\
& Sunday & 26 & 16.05 \\
& Total & 162 & 100.00 \\
\hline Year & 2008 & 09 & 5.56 \\
& 2009 & 26 & 16.04 \\
& 2010 & 26 & 16.04 \\
& 2011 & 34 & 20.99 \\
& 2012 & 40 & 24.68 \\
& 2013 & 17 & 10.49 \\
& Total & 162 & 100.00 \\
\hline
\end{tabular}

Regarding the agent used in the selfextermination attempts (Table 5), the most common was the use of medication, with $62(34.07 \%)$ cases. Intake of other chemicals, which include disinfectants and pesticides for agricultural use, were quantified in 38 cases $(20.88 \%)$. It shows that the number of agents exceeds the sample number; once between the 162,18 patients $(11.11 \%)$ used more than one agent in the attempt to selfextermination.

Table 5. Distribution, relative and absolute frequencies regarding the agents used in self-extermination attempts. Uberlândia, 2008-2013.

\begin{tabular}{lcc}
\hline Agents & $\mathbf{n}$ & \% \\
\hline Medication & 62 & 34.07 \\
Other chemical products & 38 & 20.88 \\
Melee weapons & 35 & 19.23 \\
Strangulation & 22 & 12.09 \\
Others & 15 & 8.24 \\
Precipitation & 5 & 2.75 \\
Burn & 3 & 1.65 \\
Firearms & 2 & 1.10 \\
Total & 182 & 100.00 \\
\hline
\end{tabular}


The patient's arrival was performed by the city's Fire Department, through their own prehospital service, with 83 cases $(51.23 \%)$. In 15 cases $(9.26 \%)$ the transportation was performed by ambulance, $14(8.64 \%)$ patients came through private transportation and $05(3.09 \%)$ patients arrived by other means of transportation. Medical records in which did not contain any record regarding the way patients were brought to the emergency room were a total of $45(27.28 \%)$ cases.

According to the previous medical records from patients who were brought to the hospital after the self-extermination attempt, $67(35.83 \%)$ had a mental disorder, $50(26.74 \%)$ made use of legal substances and 27 (14.44\%) had records of illegal substance usage in a regular basis. One patient $(0.53 \%)$ was physically disabled and $42(22.46 \%)$ were registered under other morbidities.

Regarding the matter of whether it was the first self-extermination attempt or not, 74 patients $(45.67 \%)$ tried self-extermination for the first time, while for 57 patients $(35.19 \%)$ were not their first attempt of self-extermination and in 31 (19.14\%) cases there were no records whatsoever. From those who had previous history of self-extermination attempts, 22 (38.60\%) were men and $35(61.40 \%)$ were women.

Only 65 medical records $(40.12 \%)$ had the cause related to the attempt. Among them, 41 $(39.42 \%)$ cases were because of a relationship conflict with the partner, $32(30.77 \%)$ were caused by family conflicts and $31(29.81 \%)$ showed other reasons.

Regarding the occurrences' evolution, 88 (54.32\%) patients were discharged after care in the emergency room; 48 (29.63\%) were admitted in another sector within the hospital; 14 (8.64\%) evaded and $12(7.41 \%)$ gave up. In this context, the average time in which the patient was in the emergency room was of 18 hours $(\mathrm{SD}=25)$.

Regarding the recidivism of the selfextermination attempts, within established period, $35(21.60 \%)$ returned to the emergency room after the first attempt identified in the gathered data. On Table 6 , the distribution of relative and absolute frequencies was found, according to gender. Later on the self-extermination attempts observed were six times the maximum rate of recidivism.

Table 6. Distribution of absolute and relative frequencies regarding the amount of recidivism in selfextermination attempts, according to gender, after the first entry in the emergency room, in January 2008 and in September 2013. Uberlândia, 2008-2013.

\begin{tabular}{lcccccc}
\hline $\begin{array}{l}\text { Later } \\
\text { Attempts }\end{array}$ & \multicolumn{2}{c}{ Men } & \multicolumn{2}{c}{ Women } & \multicolumn{2}{c}{ Total } \\
\hline & $\mathbf{n}$ & $\mathbf{\%}$ & $\mathbf{N}$ & $\mathbf{\%}$ & $\mathbf{n}$ & \% \\
One & 06 & 66.67 & 15 & 57.69 & 21 & 60.00 \\
Two & 02 & 22.22 & 05 & 19.23 & 07 & 20.00 \\
Three & 00 & 0.00 & 03 & 11.54 & 03 & 8.58 \\
Four & 01 & 11.00 & 01 & 3.85 & 02 & 5.71 \\
Six & 00 & 0.00 & 02 & 7.69 & 02 & 5.71 \\
Total & 09 & 100.00 & 26 & 100.00 & 35 & 100.00 \\
\hline
\end{tabular}

Table 7. $X^{2}$ values found, when applied the Chi-squared distribution, to the frequencies obtained by patients on both genders, regarding the agents used on the self-extermination attempts. Uberlândia, 2008-2013.

\begin{tabular}{lccccc}
\hline \multicolumn{1}{c}{ Agents } & \multicolumn{2}{c}{ Men } & \multicolumn{2}{c}{ Women } & $\mathbf{X}^{\mathbf{2}}$ \\
\hline Medication & $\mathbf{n}$ & $\mathbf{\%}$ & $\mathbf{n}$ & $\mathbf{\%}$ & \\
Other Chemical & 12 & 15.19 & 50 & 48.54 & $24.43^{*}$ \\
Products & 12 & 15.19 & 26 & 25.24 & 3.03 \\
Burn & 0 & 0.00 & 3 & 2.91 & $\mathrm{xxx}^{* *}$ \\
Precipitation & 4 & 5.06 & 1 & 0.97 & $\mathrm{xxx}^{* *}$ \\
Fire Arms & 1 & 1.27 & 1 & 0.97 & $\mathrm{xxx}^{* *}$ \\
Melee Weapons & 23 & 29.11 & 12 & 11.65 & $8.69^{*}$
\end{tabular}




\begin{tabular}{lccccc} 
Strangulation & 19 & 24.05 & 3 & 2.91 & $18.71^{*}$ \\
Others & 8 & 10.13 & 7 & 6.80 & 0,61 \\
Total & 79 & 100.00 & 103 & 100.00 & - \\
\hline
\end{tabular}

$(*) \mathrm{p}<0,05 ;(* *)$ the test could not be applied due to the low frequencies found.

According to the results shown in table 7 , statistically significant differences were found between frequencies of male and female patients when the following variables are concerned: medications with positive frequencies higher among patients from the female group; melee weapons and strangulation were higher among patients from the male group.

\section{DISCUSSION}

Several studies have shown that selfextermination attempts are more common among female patients, with rates between $50 \%$ and $80 \%$ (SÁ, et al., 2010; SANTANA, et al., 2011; TREVISAN, SANTOS, OLIVEIRA, 2013; VIDAL, GONTIJO, LIMA, 2013; ROSA, et al., 2015, BERNARDES, TURINI, MATSUO, 2010). In this study, the same proportion of women who tried selfextermination is maintained, being found a rate of $56.17 \%$.

Attempts of self-extermination by individuals within the age of 10 to 24 years old could be observed, prevailing attempts from the female group, with a minimum age of 12 years old. A research about the epidemiological profile of children and teenagers who attempted suicide and committed suicide by intoxication, performed by Rosa and collaborators (2015) pointed a prevalence of the female group. These authors observed that earlier ages had a higher frequency of selfextermination attempts among male patients, with a proportion of one, with age below 10 years old, to five with age between 10 and 14 years old from the female group; and one to thirty-four in the female group, which differs in this study.

The age group with highest frequency was the one between 24 and 38 years old, which corroborates with the present literature, seen that some studies report a prevailing age group between 20 and 30 years old (SÁ, et al., 2010; SANTANA, et al., 2011; TREVISAN, SANTOS, OLIVEIRA, 2013). The age range includes the economically active population, recently called as population with active age, according to the Economic Applied Research Institute - IPEA (2014), concerning individuals with age from 20 to 49 years old. Just as the proper suicide, the suicide attempt shows costs to society. First, as said earlier, implies the loss of human resources, and second, the loss of public resources that could be destined to other matters (GONÇALVES, GONÇALVES, OLIVEIRA JUNIOR, 2011), since the treatments are considered expensive. In 2002, the onus generated by suicide attempts, at a global level, were $1.4 \%$, and values of $2.4 \%$ are estimated to 2020 (BRASIL, OPAS, UNICAMP, 2006).

Less lethal methods, like the selfextermination attempt by exogenous intoxication, are considered prevalent, mostly among the female population, while male individuals use strangulation, cutting and/or piercing objects more often (SÁ, et al., 2010; SANTANA, et al., 2011; VIDAL, GONTIJO, LIMA, 2013; TREVISAN, SANTOS, OLIVEIRA, 2013). In this research, there was statistically significant difference as to the frequency of medication usage in attempts of selfextermination, being more common by the female group. The male group presented positive frequencies to the usage of melee weapons and strangulation, hence, this data is consistent with present literature.

Recurrences were also more frequently among women, as shows the self-extermination attempt profiling in some researches (SANTANA, et al., 2011; VIDAL, GONTIJO, LIMA, 2013). This study found previous histories and recurring returns due to self-extermination attempts, drawing the recurrence picture, presenting women in higher number, findings that are consistent with the present literature. Santana and collaborators (2011) attribute the female group's recidivism by the usage of less lethal methods, when compared to the male group. In fact, men present a lower recurrence rate, since the obit is accomplished by the suicide attempt, through more aggressive agents.

Therefore, the means used to achieve selfextermination may be involved with gender construction matters established by our society (SANTANA, et al., 2011) whose lethality is related to demonstration of strength and power. To Souza, Minayo and Cavalcante (2007), in cases of selfextermination attempts by women they are relevant to patriarchy, residency restrictions, absence of support in social networks, violence inside family circles and victimization caused by physical, psychological and sexual abuse as well as abuse by negligence. 
Sá and Collaborators (2010) state that private transportation was mostly used to arrive at urgency and emergency services; in second place was the Mobile Urgency Care - SAMU. However, in this study, it was noted that the arrival to the emergency room was carried out by the Fire Department. In Brazil, the public prehospital mobile care is only performed by SAMU and the Fire Department (CONSELHO FEDERAL DE MEDICINA, 2014). However, there's no SAMU service installed in the city of Uberlândia, hence the Fire Department being the only public prehospital service available.

The use of medications was shown as the most used agent to self-extermination attempts, followed by intoxication by other chemical agents. In other studies, the same pattern was observed, being exogenous intoxication, in a general way, found among those who tried self-extermination (SÁ, et al., 2010; SANTANA, et al., 2011, TREVISAN, SANTOS, OLIVEIRA, 2013; VIDAL, GONTIJO, LIMA, 2013). Thereby, it looks as though it is a warning sign of the easy access to these agents, especially in home environment, configuring as a risk factor (ROSA, et al, 2015; TREVISAN, SANTOS, OLIVEIRA, 2013).

In a research developed by an Intoxication Control Center in Paraná, among all cases tended to between 1997 and 2007, the most frequent pharmacological group were tranquilizers, antidepressants, anticonvulsants and antiinflammatory. Therefore, a more careful patient's evaluation is needed by the prescriber, regarding, primarily, the psychoactive medication group, since this group can be used in self-extermination attempts (BERNARDES, TURINI, MATSUO, 2010).

It was noticed that Mondays was the day of the week with highest frequency of attendance. In a research, Santana and Collaborators (2011) noticed that there was a higher rate of self-extermination attempts on Sundays, Mondays and Fridays. According to the authors, days prior and after the weekend can cause feelings such as solitude, anguish, depression and despair become more evident.

Individuals with mental disorders were at higher risk for suicide, as well as previous history of suicide attempts (BRASIL, OPAS, UNICAMP, 2006; WHO, 2012). Job losses, the end of relationships and social stress are pointed as circumstantial risk factors for self-extermination attempts (WHO, 2012). The main reason, observed in this study, that triggers the decision for the selfextermination act were mostly relationship conflicts.
However, the protection factors may be the support needed by family and community; developing the ability to solve problems, conflicts, beliefs that support self-preservation and accessible care (WHO, 2012). Despite the urgency and emergency services professionals often deal with circumstances of self-extermination; the basic healthcare and Psychosocial Attention Centers CAPS are the ones with a privileged position to elaborate strategies to reinforce social protection networks and risk evaluation (BRASIL, OPAS, UNICAMP, 2006; VIDAL, GONTIJO, 2013). Therefore, urgency and emergency care services, despite the frequent contact with these cases, are just part of the whole process, set as a curative matter. If healthcare, as an accepted concept, walks beyond the "being or not being sick", working with matters of enhancing quality of life and prevention are also parts of the strategy against cases of selfextermination.

In May $16^{\text {th }}$ of 2001 , through gateway number $737 \mathrm{MS} / \mathrm{GM}$, the National Policy for Reduction of Morbidity and Mortality by Accidents and Violence, through formulation of systematized and articulated actions was approved. The directive that guides this policy involves the promotion of safe environments, systematization, expansion and consolidation of the prehospital service; interdisciplinary and intersectoral assistance to victims of violence and accidents; structuring and consolidation of services focused on recovery and rehabilitation; training of human resources; monitoring the occurrence of accidents and violence; supporting the development of studies and research.

As exposed, one of the directives of this policy that aims the reduction of morbidity and mortality caused by accidents and violence is vigilance of these cases (BRASIL, 2005). Therefore, in 2006, the system for Violence and Accident Vigilance (VIVA) was created, gathering data and generating information about such matters and, thus, helping to develop actions to prevent such harm (BRASIL, 2013). However, no database was found about preventing actions that are actually being practiced after the policy was approved.

The lack of records that involve cases whereby the patient entered by the emergency room was noticed. The Federal Medical Council (CONSELHO FEDERAL DE MEDICINA, 2002) defines, in the resolution number 1638, from July $10^{\text {th }}$ of 2002 , that the medical record becomes a legal, confidential and scientific document, containing information about the patients' healthsickness process in addition to the assistance given, 
Characterization of self-extermination...

so that way, this assistance can be continued and the communication between the multidisciplinary team is allowed. For nurses, the Code of Ethics of Nursing Professionals (CONSELHO FEDERAL DE ENFERMAGEM, 2007) states that it is the duty and responsibility of nurses registering inherent and indispensable information for care. Failure to comply may cause offense.

In this research, cases of self-extermination attempts in the emergency room of a University Hospital are characterized, being prevalent female individuals, age group between 24 and 38 years old, single, resident in Uberlândia. The sample showed a greater number of cases happening in 2012, more often during the night, on Mondays. The most used method was the intoxication by medication and the most common mean to transport the patient to emergency services was the fire department prehospital services.

There were records, in medical records, when referring to previous illnesses, showing some mental disorders among patients who attempted self-extermination. And concerning previous history of self-extermination attempts, there was a higher
QUINTILIANO, D. C.; FERREIRA, M. C. M.

frequency among those who had made the first attempt to self-extermination. The main reason behind the attempt was a relationship conflict. However, it was observed a high rate of unregistered reasons behind the attempt. The time of permanence inside the emergency room was of 18 hours, on average. When evaluating the history of previous return to the emergency room by selfextermination attempt, the residency was more frequent among women.

This research presented some limitations when comes to sample diminishing. The medical records, that originally had diagnostics of selfextermination attempts in the concerned medical database service, when analyzed, had cases that did not fit in a self-extermination attempt description. There were also medical records that had insufficient information for data gathering.

Researches with higher samples and periods of time, that were analyzed by The National Policy for Reduction of Morbidity and Mortality by Accidents and Violence, created by the Ministry of Health, are most suggested.

RESUMO: A violência se torna uma questão a ser discutida no processo saúde doença, uma vez que atinge a saúde coletiva e individual, exigindo atuação e articulação dos serviços. O suicídio é a $3^{\text {a }}$ causa de morte no Brasil, todavia os registros de tentativa de autoextermínio ainda são poucos divulgados ou subnotificados. Caracterizar os casos de tentativa de autoextermínio em um Pronto Socorro de um Hospital Universitário. Trata-se de um estudo retrospectivo, transversal com abordagem quantitativa. Foram incluídos 162 prontuários com registro de tentativa de autoextermínio, referentes ao período de janeiro de 2008 a setembro de 2013. Dos 162 prontuários analisados, 56,17\% eram do sexo feminino; 22,22\% da faixa etária entre 24 e 38 anos, idade média de 34,5 anos; 53,09\% solteiros; 94,44\% procedentes de Uberlândia. 39,51\% ocorreram no período noturno; frequência de 19,14\% às segundas-feiras; 24,68\% de tentativas em 2012. A ingestão de medicamentos foi utilizada em 34,07\% dos casos; 51,23\% chegaram através do Corpo de Bombeiros; $35,83 \%$ apresentavam algum transtorno mental; $45,67 \%$ dos casos eram primeira tentativa; 39,42\% dos casos ocorreram após conflitos de relacionamento com o parceiro. 54,32\% obtiveram alta após atendimento, com 18 horas, em média no Pronto Socorro; $21,60 \%$ retornaram por outra tentativa. A pesquisa caracterizou as tentativas de autoextermínio, com predominância do sexo feminino, faixa etária de 24 a 38 anos, com uso de medicamento como agente para o ato, com alta reincidência entre o grupo de indivíduos do sexo feminino. Sugere-se pesquisas com períodos e amostras maiores, e análise pela Política de Redução de Morbimortalidade por Violências e Acidentes.

PALAVRAS-CHAVE: Tentativa de suicídio. Violência. Serviços Médicos de Emergência.

\section{REFERENCES}

BERNARDES, S. S.; TURINI, C. A.; MATSUO, T. Perfil das tentativas de suicídio por sobredose intencional de medicamentos atendidas por um Centro de Controle de Intoxicações do Paraná, Brasil. Caderno de Saúde Pública, Rio de Janeiro, v. 26, n. 7, jul. 2010.

BRASIL. Ministério da Saúde. Secretaria de Vigilância em Saúde. Departamento de Análise de Situação de Saúde. Política nacional de redução da morbimortalidade por acidentes e violências: Portaria MS/GM n. ${ }^{\circ}$ 737 de 16/5/01, publicada no DOU n. ${ }^{\circ} 96$ seção 1E de 18/5/01. 2. ed. Brasília: Editora do Ministério da Saúde, 2005. Available: <http://dtr2001.saude.gov.br/editora/produtos/livros/pdf/05_0742_M.pdf>. Access: Dec. 2013. 
. Ministério da Saúde. Secretaria de Vigilância em Saúde. Mortalidade por acidentes e violências no Brasil: situação em 2010 e tendências de 2001 a 2010. In: Saúde Brasil 2011: uma análise da situação de saúde e a vigilância da saúde da mulher. Brasília: Ministério da Saúde, 2012. cap. 10.

. Ministério da Saúde. Secretaria de Vigilância em Saúde. Departamento de Vigilância de Doenças e Agravos não Transmissíveis e Promoção da Saúde. Sistema de Vigilância de Violências e Acidentes (Viva): 2009, 2010 e 2011. Brasília: Ministério da Saúde, 2013. Available:

$<\mathrm{http} / / /$ bvsms.saude.gov.br/bvs/publicacoes/sistema_vigilancia_violencia_acidentes.pdf $>$. Access:Nov. 2013.

BRASIL, Ministério da Saúde; ORGANIZAÇÃO PAN-AMERICANA DE SAÚDE - OPAS;

UNIVERSIDADE ESTADUAL DE CAMPINAS - UNICAMP. Prevenção de suicídio: manual dirigido a profissionais das equipes de saúde mental. Campinas: Ministério da Saúde; 2006. Available:

$<$ http://portal.saude.gov.br/portal/arquivos/pdf/manual_prevencao_suicidio_saude_mental.pdf $>$. Access: Aug. 2013.

CONSELHO FEDERAL DE ENFERMAGEM. Código de Ética dos Profissionais de Enfermagem. Resolução COFEN n 311/2007. Aprova a Reformulação do Código de Ética dos Profissionais de Enfermagem. COFEN, Rio de Janeiro, 08 fev. 2007.

CONSELHO FEDERAL DE MEDICINA. Resolução CFM nº 1.638, de 10 de julho de 2002. Define prontuário médico e torna obrigatória a criação da Comissão de Revisão de Prontuários nas instituições de saúde. Diário Oficial da União, Brasília, Seção I, 9 ago. 2002, p.184-5. Available:

$<$ http://www.camara.gov.br/sileg/integras/257309.pdf>. Access: Apr. 2015.

. Resolução CFM n ${ }^{\circ}$ 2.110/2014. Dispõe sobre a normatização do funcionamento dos Serviços PréHospitalares Móveis de Urgência e Emergência, em todo o território nacional. Diário Oficial da União, Brasília, Seção I, 19 nov. 2014, p. 199 - 200. Available:

$<$ http://pesquisa.in.gov.br/imprensa/jsp/visualiza/index.jsp?jornal=1\&pagina=200\&data=19/11/2014>. Access: Mar. 2015.

GONÇALVES, L. R. C.; GONÇALVES, E.; OLIVEIRA JUNIOR, L. B. Determinantes espaciais e socioeconômicos do suicídio no Brasil: uma abordagem regional. Nova economia, Belo Horizonte, v. 21, n. 2, ago. 2011.

INSTITUTO DE PESQUISA ECONÔMICA APLICADA - IPEA. Mercado de Trabalho. In: Carta de

Conjuntura. Brasília: IPEA, mar. 2014. Cap. 2, p. 31 - 41. Available:

$<$ http://www.ipea.gov.br/agencia/images/stories/PDFs/conjuntura/cc22_mercadodetrabalho.pdf $>$. Access: Feb. 2015.

MINAYO, M. C. S. Violência: um problema para a saúde dos brasileiros. In: BRASIL. Ministério da Saúde. Secretária de Vigilância em Saúde. Impacto da violência na saúde dos brasileiros. Brasília: Ministério da Saúde, 2005. cap. 1.

Suicídio: violência auto-infligida. In: BRASIL. Ministério da Saúde. Secretária de Vigilância em Saúde. Impacto da violência na saúde dos brasileiros. Brasília: Ministério da Saúde, 2005. cap. 7.

ROSA, N. M.; CAMPOS, A. P. S.; GUEDES, M. R. J.; SALES, C. C. F.; MATHIAS, T. A. F.; OLIVEIRA, M. L. F. Intoxicações associadas às tentativas de suicídio e suicídio em crianças e adolescentes. Revista de Enfermagem UFPE on line, Recife, v. 9, n. 2, p. 661-8, fev. 2015. Available:

<http://www.revista.ufpe.br/revistaenfermagem/index.php/revista/article/viewFile/7466/pdf_7172>. Access: Feb. 2015.

SÁ, N. N. B.; OLIVEIRA, M. G. C.; MASCARENHAS, M. D. M.; YOKOTA, R. T.C.; SILVA, M. M. A.; MALTA, D. C. Atendimentos de emergência por tentativas de suicídio, Brasil, 2007. Revista Médica de Minas Gerais, Belo Horizonte, v. 20, n. 2, p. 145-152, 2010. 
SANTANA, J. C. B.; FARIA, R. A. D.; DUTRA, B. S.; HANG-COSTA, T. A.; SOUZA

H. N. F.; VIEIRA, L. S.; MOURA, I. C. Caracterização das vítimas de tentativa de autoextermínio atendidas pelo Serviço de Atendimento Móvel de Urgência (SAMU) no município de Sete Lagoas e região. Revista Bioethikos, São Paulo, v. 5, p. 84-92, 2011.

SIEGEL, S. Estatística não-paramétrica, para as ciências do comportamento. São Paulo: McGraw-Hill do Brasil, 1975. p. 350.

SOUZA, E. R.; MINAYO, M. C. S.; CAVALCANTE, F. G. O impacto do suicídio sobre a morbimortalidade da população de Itabira. Ciência \& Saúde Coletiva, Rio de Janeiro, v. 11, p. 1333-1342, 2007.

TREVISAN, E. P. T.; SANTOS, J. A. T.; OLIVEIRA, M. L. F. Tentativa de suicídio de mulheres: dados de um Centro de Assistência Toxicológica do Paraná. Revista Mineira de Enfermagem, Belo Horizonte, v. 17, n. 2, p. 412-417, abr/jun 2013.

VIDAL, C. E. L.; GONTIJO, E. D. Tentativas de suicídio e o acolhimento nos serviços de urgência: a percepção de quem tenta. . Caderno de Saúde Coletiva, Rio de Janeiro, v. 21, n. 2, 2013. Available: <http://www.scielo.br/pdf/cadsc/v21n2/02.pdf>. Access: Dec. 2013.

VIDAL, C. E. L.; GONTIJO, E. C. D. M.; LIMA, L. A. Tentativas de suicídio: fatores prognósticos e estimativa do excesso de mortalidade. Caderno de Saúde Pública, Rio de Janeiro, v. 29, jan. 2013. Available: $<$ http://www.scielo.br/pdf/csp/v29n1/20.pdf>. Access: Nov. 2013.

WORLD HEALTH ORGANIZATION - WHO. Preventing violence and reducing its impact: How development agencies can help. Switzerland, 2008. Available:

<http://whqlibdoc.who.int/publications/2008/9789241596589_eng.pdf>. Access: Oct. 2013.

. Ação de saúde pública para a prevenção do suicídio. Switzerland: 2012. Available:

<http://site.cfp.org.br/wp-content/uploads/2013/07/documento-suic\%C3\%ADdio-traduzido.pdf >. Access: dec. 2013. 